\title{
Article \\ Drivers of Digitalization in the Energy Sector-The Managerial Perspective from the Catching Up Economy
}

\author{
Justyna Światowiec-Szczepańska ${ }^{1, *}$ and Beata Stępień ${ }^{2}$
}

1 Department of International Finance, Poznan University of Economics and Business, Niepodległości 10, 61-875 Poznań, Poland

2 Department of International Management, Poznan University of Economics and Business, Niepodległości 10, 61-875 Poznań, Poland; beata.stepien@ue.poznan.pl

* Correspondence: justyna.swiatowiec-szczepanska@ue.poznan.pl

Citation: Światowiec-Szczepańska, J.; Stępień, B. Drivers of Digitalization in the Energy Sector-The Managerial Perspective from the Catching Up Economy. Energies 2022, 15, 1437. https://doi.org/10.3390/ en15041437

Academic Editors: David Borge-Diez and Marek Szarucki

Received: 19 January 2022

Accepted: 11 February 2022

Published: 16 February 2022

Publisher's Note: MDPI stays neutral with regard to jurisdictional claims in published maps and institutional affiliations.

Copyright: (c) 2022 by the authors. Licensee MDPI, Basel, Switzerland. This article is an open access article distributed under the terms and conditions of the Creative Commons Attribution (CC BY) license (https:// creativecommons.org/licenses/by/ $4.0 /)$.

\begin{abstract}
This article attempts to identify the key forces driving the successful digitalization of the energy sector, ensuring improvements in the energy triangle including sustainability, stability, and economic performance. The article sheds light on the diverse energy priorities at supra-, national and managerial levels, and the role of digitalization in achieving these objectives. Catching up economies (such as Poland), being post-socialist EU member states, in order to transform its energetic sector, must overcome a number of infrastructural and social shortcomings retained as a legacy of the socialist economy. As such, sustainability (as the core priority at EU energy agenda) may not be the leading objective at both national and company level in the energy sector transformation. This article presents the results of empirical research carried out through distribution of e-questionnaire addressed to Polish managers from the energy sector. The results were analyzed using the fsQCA method. The findings suggest that, for managers, the most important drivers of digitalization and transformation of the energy sector in Poland are its high economic performance, together with support for energy prosumers and consumers. The prerequisites for a successful digitalization are alternatively the absence of management barriers, or a combination of high economic performance and a strong focus on environmental protection. Surprisingly, according to managers surveyed, the rapid implementation of new technologies is not considered a vital condition for successful digital transformation of the energy sector, which implies either or managerial lack of knowledge in this area and/or a reluctance to introduce digital rapid technologies.
\end{abstract}

Keywords: energy sector; digitalization; sustainability; catching up economy; fsQCA

\section{Introduction}

Electricity sourcing, production, and transmission serves as the economic lifeblood of any economy, and, together with the transport and communication system, determines its efficient functioning [1-5]. Due to the interdependence of economic development on access to energy, this sector is the subject of strategic state protection, and often a large part of the infrastructure (especially mining and transmission) remains public. The security and stability of the energy system depends on ensuring stable supply, hence diversification of sources and energy self-sufficiency is a strategic priority for states. The efficient functioning of the energy sector is also necessary for ensuring economic growth. However, economic development and steady increase in energy demand comes with increasing environmental costs. Ensuring both sources of energy and ways of its non-environmentally harmful transmission and distribution becomes a global challenge.

The global energy sector is currently a subject of multi-fold change. Energy transition towards an environmentally friendly, low emission energy system is fueled by decarbonization, digitalization, and decentralization (the 'three Ds') (Terminology abbreviations used in this work are included in Table A1 in the Appendix A), three major, intertwined trends [6]. 
The digitalization of the energy sector can greatly facilitate this transformation. Practitioners, politicians, and the academic community perceive digitalization as the key factor for rapid, efficient, and balanced development of energy sector that will help to achieve all priorities stated in the energy triangle, such as sustainable development, energy stability (security), and sector competitiveness (efficiency, economic performance) [7-9].

Gaining a detailed understanding of the expected use of digital technologies, together with the benefits of and barriers to digitization, is essential for defining goals, guidelines, and detailed programs for achieving digital transformation in specific regions or countries. Potential risks and bottlenecks should be analyzed at the enterprise, societal, and country levels in order to develop ways to address barriers to achieving successful digitization and energy transformation. This article adopts a managerial perspective on the premise that regardless of energy policy goals, guidelines, and programs, it is the managers and employees of the energy sector who are responsible for their implementation. Therefore, it is worth exploring their opinion to gain an idea of what transformational benefits they see in the digitalization of the sector and what difficulties they face in the process.

While environmental and sustainable goals being vital are justified economically and socially in the long term, their implementation is costly and challenging, especially for those EU members that still belong to the catching up economies. New European Union countries belonging to this category share a common socialist heritage with a variety of shortcomings: the old infrastructure being dependent on traditional fuels and the privileges of certain social groups (e.g., miners) have been entrenched for decades [10-12]. Even though these countries differ from each other (e.g., in terms of the size and scale of the energy transition challenge), they are still catching up with the developed part of the world in terms of infrastructure, economy, and society, therefore the environmental goals of EU social policy might not be recognized as a priority for them.

Studies on the role of digital technologies in the energy sector transition have focused mainly on the macro level, showing how efficiency, integration, and sustainability goals set on the supranational (here, meaning the EU level) have been achieved by individual countries/ EU members [3,4]. In turn, studies on the application of digital technologies in the energy sector reveal which of these technologies are predominantly used and what benefits and costs they generate [13-19]. There is a distinct paucity in analysis of how managers (especially from countries where the palette of transformational challenges in the energy sector is much larger than in mature economies) perceive the digitalization transformation of this sector, as well as what type of goals digitalization will help achieve. Learning about the views of this group will allow for more accurately answering the question about the prospects for the implementation of energy sector transformation programs at national and EU levels, as it will reveal not only which digital technologies will help to implement particular priorities, but will also make it possible to discover the threats connected with this transformation. In this paper, we explore the main drivers of the digitalization of the energy sector in Poland: a country which is an example of a catching up economy which also forms part of the EU supranational socio-political-economic community, pursuing an ambitious energy policy aimed at environmental neutrality and sustainability. The goal is to detect the main drivers of sector digitalization and barriers that must be overcome in order to transform it with digital technologies introduction and usage. In this paper, we state the following research questions:

$R Q 1$. What are the expectations from the digitalization of the energy sector in European countries? $R Q 2$. What are the most important drivers for digital technologies in the energy sector in Poland, a country classified as a catching up economy?

$R Q 3$. What are the barriers to digitalizing the energy sector in a country catching up with Europe's economic leaders?

A mixed methods approach of data acquisition and analysis was adopted to answer the questions posed above. In order to obtain data, an e-questionnaire was created on the basis of literature analysis and interviews with experts from the energy sector. It was distributed to managers responsible for the transformation of the energy sector in Poland. 
The obtained data (44 responses), received in November 2021, were analyzed using fuzzy set Qualitative Comparative Analysis (fsQCA). Using fsQCA allowed for the identification of the most significant drivers in the digital transformation of the energy sector in Poland.

The rest of the paper is organized as follows. In the theoretical part, we present the main trends of digital transformation of the energy sector as challenges for transnational and national policies. Then, we identify expectations related to the digitalization of the energy sector at macroeconomic and microeconomic level. We indicate their relationship with the objectives of the European Union's energy policy, taking into account countries with the greatest delays in energy transformation. We further identify potential barriers to digitalization of the energy sector, in particular those perceived at the managerial level. The result of the theoretical considerations is the conceptual model of the expected effects of digitalization of the energy sector showing the main driving forces and factors hindering successful digitalization. The empirical part of the article includes a description of the research method and analysis of the results. The article ends with a discussion of the obtained results and conclusions.

\section{Theoretical Background}

\subsection{Digitalization of the Energy Sector}

The digital transformation of the energy sector has taken place worldwide for many years $[8,20,21]$. This sector has long been a pioneer in the application of new technologies (IT), and in recent years it has been experiencing tremendous changes, associated with the fourth industrial revolution, called Industry $4.0[22,23]$. The pace of digitalization in the power industry is accelerating. Over the past few years, energy companies have been heavily invested in digital technologies. As reported by the International Energy Agency, global investment in digital power infrastructure and software has increased by more than 20\% per year since 2014, reaching $\$ 47$ billion in 2016. Digital investments in 2016 were nearly $40 \%$ higher than investments in the natural gas power industry worldwide (\$34 billion) [24]. The underpinning of these changes in many countries, particularly in EU member states, was substantial in liberating the electricity market and introducing new renewable energy regulations was

In order to analyze digital trends, it is important to distinguish between the concepts of digitization and digitalization [25]. Digitization is the process of capturing, editing/using, and storing analog information on digital storage media. Digitalization, also known as digital transformation, refers to the application of digital technologies to improve business, policy, or decisions in general in order to increase overall efficiency, cost, security, and sustainability [26]. According to Vial [27], digital transformation is "a process that aims to improve an entity by triggering significant changes to its properties through combinations of information, computing, communication, and connectivity technologies." The International Energy Agency (IEA) states that digitalization means a growing interdependence of the digital and physical spheres, due to the increasing use of ICTs in daily life [24]. In the energy sector, digitalization provides the necessary infrastructure and interfaces to enable smart and efficient functioning of operations and operators.

According to experts, the most important global digital trends that will be actively implemented in the energy industry of the near future are the decentralization of power generation, the digitalization of infrastructure, intelligent control and engineering, or the creation of new opportunities for end consumers of energy [28]. A significant digital trend for the development of the energy sector is also transforming grid networks into smart grids [21], electricity networks that allow for the processing, control, and management of the enormous data flow [29].

The most frequently mentioned digital technologies, already applied in the energy sector (although still not widely used) are: artificial neural networks (ANN), artificial intelligence (AI), blockchain, Internet of Things (IoT) robotic process automation (RPA), machine learning, big data mining, or cloud computing $[25,26,30]$. All technologies listed here: 
- are interdependent and support each other (e.g., blockchain uses big data mining, cloud computing, can operate more efficiently by using ANNs, contributes to AI and IoT);

- are largely universal: they are applicable in many spheres of social and economic life; - their application entails comprehensive benefits.

From a list of new technologies applicable in various industries, including the energy sector, the following deserve special attention: blockchain, ANN, and AI. The reason for this choice is that:

- they use or enable the development of the other listed technologies and applications;

- they have wide applicability of use; and

- they provide all the benefits regarding stability, efficiency, and environmental sustainability of the energy sector.

Blockchain technology enables the efficient management of the growing complexity of the energy sector's structure and networks through the controlled use of data (while ensuring its sovereignty) and direct interaction between actors (i.e., allows for disintermediation) by comprehensively and simultaneously monitoring energy flows at low cost and in detail, regardless of their size and distance [31-33]. The greatest potential and, at the same time, benefits of applying this technology are primarily revealed in direct transactions between customers and energy suppliers (including prosumers). Blockchain technology, thanks to disintermediation, enables the direct transfer of energy from competing suppliers and facilitates financial settlements between these entities and clients, including the simplification and possible reduction of the volume of taxes or administrative fees. By controlling all the links in the process, blockchain technology also ensures security of supply by providing information on the origin of energy.

Even more promising, considering benefits of use in the energy sector, are artificial neural networks that enable to analyze information in a novel way. Artificial neural networks, as the proverbial doorway to artificial intelligence (AI), are mathematical and computer models that mimic the work of neurons and a human brain. They are a system of interacting processes, able to analyze information and learn, remember, and reproduce images, identify patterns, and generate solutions [34].

The application of artificial neural networks and the AI based on them in the energy industry is impressively multi-stage and multi-area. They can be used in the following stages of the energy value chain:

- power network design: in forecasting energy demand and assessing the reliability of generation equipment, automating protection, and controlling systems' overload in production and transmission;

- energy generation: for the prevention and cost optimization of equipment operation;

- transmission and sales: automating the selection of the most cost-effective/ strategic suppliers, etc., dynamic differentiation and optimization of energy prices depending on season customer habits, automation of billing, etc.

The use of artificial neural networks in the power industry is already evident in many countries around the world. The use, benefits, and prerequisites, as well as possible risks of using digital technologies, have already been analyzed, for example in the UK $[13,14,35]$, Germany [26] USA [15], Norway [21], China [16,17], or Russia [18,19].

The energy sector transformation, driven by new digital technologies, makes it attractive to new private investors and implies increased competition with new business models introduced. The current wave of digitization is also driven by consumer demand seeking advanced digital services or products. Every company in the energy sector is therefore facing the need to prepare itself for digital transformation to be able to face and survive in novel, fierce competition game. 


\subsection{Objectives and Benefits of the Energy Sector Digitalization}

The complexity and interdependence of digitalization outcomes in the energy sector makes its classification difficult. Based on a thorough and extensive literature review, Weigel and Fischedick [26] classified digitalization benefits in the energy sector with respect to: (1) system stability; (2) environmental protection; (3) energy demand reduction; (4) revenue enhancement; (5) cost reduction; and (6) customer satisfaction. Table 1 describes the main uses and benefits of the most important digital technologies in the energy sector with regard to EU energy policy objectives. The six subcategories (smart grid and optimized operation, smart market and flexibility integration, anomaly detection and prediction, process efficiency, smart home, trust and transparency) account for a broad spectrum of benefits, as they cover a large number of individual digital applications [26].

Table 1. Digital applications and their use and benefits in the energy sector.

\begin{tabular}{|c|c|c|c|}
\hline & $\begin{array}{c}\text { Main Benefits of } \\
\text { Digital Transformation }\end{array}$ & $\begin{array}{l}\text { Applications of Digital } \\
\text { Technology in the Energy } \\
\text { Industry }\end{array}$ & $\begin{array}{c}\text { Types of Digital Technology } \\
\text { Most Used in the Energy } \\
\text { Industry }\end{array}$ \\
\hline 2. & $\begin{array}{l}\text { System security and } \\
\text { stability and cost } \\
\text { reduction } \\
\text { Environmental } \\
\text { protection }\end{array}$ & $\begin{array}{c}\text { Smart grid and optimized } \\
\text { operations }\end{array}$ & $\begin{array}{c}\text { Blockchain } \\
\text { Artificial neural networks (ANN), } \\
\text { Artificial intelligence (AI) } \\
\text { Robotic process automation } \\
\text { Machine learning } \\
\text { Big data } \\
\text { Cloud computing }\end{array}$ \\
\hline 2. & $\begin{array}{l}\text { System security and } \\
\text { stability and cost } \\
\text { reduction } \\
\text { Environmental } \\
\text { protection }\end{array}$ & $\begin{array}{l}\text { Smart market and } \\
\text { flexibility integration }\end{array}$ & $\begin{array}{c}\text { Internet of Things (IoT) } \\
\text { Artificial neural networks (ANN), } \\
\text { Artificial intelligence (AI) } \\
\text { Blockchain } \\
\text { Big data } \\
\text { Cloud computing }\end{array}$ \\
\hline $\begin{array}{l}1 . \\
2 .\end{array}$ & $\begin{array}{l}\text { System security and } \\
\text { stability } \\
\text { Cost reduction }\end{array}$ & $\begin{array}{l}\text { Anomaly detection and } \\
\text { prediction }\end{array}$ & $\begin{array}{c}\text { Artificial neural networks (ANN), } \\
\text { Artificial intelligence (AI) } \\
\text { Robotic process automation (RPA) } \\
\text { Machine learning } \\
\text { Big data } \\
\text { Cloud computing }\end{array}$ \\
\hline 1. & Cost reduction & Process efficiency & $\begin{array}{c}\text { Artificial neural networks (ANN), } \\
\text { Artificial intelligence (AI) } \\
\text { Robotic process automation (RPA) } \\
\text { Blockchain } \\
\text { Machine learning } \\
\text { Big data } \\
\text { Cloud computing }\end{array}$ \\
\hline $\begin{array}{l}1 . \\
2 .\end{array}$ & $\begin{array}{l}\text { Environmental } \\
\text { protection } \\
\text { Customer satisfaction }\end{array}$ & Smart home & $\begin{array}{c}\text { Internet of Things (IoT) } \\
\text { Artificial intelligence (AI) } \\
\text { Blockchain } \\
\text { Big data } \\
\text { Cloud computing }\end{array}$ \\
\hline $\begin{array}{l}1 . \\
2 .\end{array}$ & $\begin{array}{l}\text { Customer satisfaction } \\
\text { System security } \\
\text { and stability }\end{array}$ & Trust and transparency & $\begin{array}{l}\text { Blockchain } \\
\text { Big data } \\
\text { Cloud computing }\end{array}$ \\
\hline
\end{tabular}

A common feature of most lists describing digitalization benefits is that they are analyzed comprehensively, without discussing its importance at the management level. However, not all benefits, vital for global energy policy, can be considered as such at the managerial level. Even though macroeconomic and microeconomic benefits are interde- 
pendent and affect the global energy economy, separating them into these more relevant to companies and those crucial to state or regional policy politics allows to capture differences between those two perspectives on the same issue.

Below, we attempt to identify the main benefits at the macro and micro level, to facilitate analysis of digitalization challenge from a company and managerial perspective.

\subsubsection{The Role of Digitalization in Achieving Global and Regional Energy Transition Goals}

The goals of digital transformation of the energy sector refer to the global energy policy. The literature identifies three key objectives of this policy: (i) reducing costs, (ii) securing energy supply, while (iii) reducing climate burdens [39,40]. The terms 'energy policy triangle' or 'energy policy trilemma' [7,9] illustrate synergies and trade-offs between these potentially conflicting objectives $[6,41,42]$.

An analysis of energy policy at international level clearly shows that its main priority is the pursuit of sustainable development [43-45]. Recognition of this priority as the main driver of change in the global energy sector is a well-known fact, supported by legal arrangements. The Paris Agreement negotiated at the 21st Conference of the Parties during the United Nations Framework Convention on Climate Change in December 2015 declared a global consensus to ensure the increase in global average surface temperature remained below $2{ }^{\circ} \mathrm{C}$ from pre-industrial levels [41]. This agreement reinforced the international requirement for a low-carbon transformation of the energy sector.

The main goals of the EU energy policy are to reduce the environmental impact of its production and transmission while maintaining the security and stability of the system, in order to serve economic and social development. The objective is to create an integrated, secure, and stable European energy market (Article 194 of the Treaty on the Functioning of the European Union) [46], with the main challenges being:

- decarbonizing the economy and reducing $\mathrm{CO}_{2}$ emissions;

- diversifying Europe's energy sources, including reducing dependence on energy imports;

- integration and free movement of energy within the EU.

While the integration of the energy market is dictated by security and stability considerations, the reduction of $\mathrm{CO}_{2}$ emissions results from efforts to reduce the negative environmental impact and the implementation of the principle of sustainable development in this area. Diversification of energy sources has a twofold purpose: to reduce the negative impact on the environment, and to ensure the stability and security of energy supplies. Although these three goals do not directly indicate maintaining high competitiveness of the sector, it is, next to sustainability and stability, a political priority. The sector needs to be efficient and cost-competitive to ensure that Community members grow and develop. The importance of the efficiency factor resounds in the Clean Energy for All Europeans package introduced in the EU in 2019. The package aims to achieve carbon neutrality across the Community by 2050 by gradually replacing fossil fuels with cleaner energy [43]. The assumptions of this package for 2030 (set out in the updated EU Climate and Energy Framework) are:

- $40 \%$ reduction in $\mathrm{CO}_{2}$ emissions;

- $32 \%$ share of renewable energy sources; and

- $32.5 \%$ increase in energy efficiency.

The implementation of EU energy policy objectives depends on cooperation between Member States, and, as such, should contribute to greater transparency of the entire market by eliminating technical and regulatory barriers. The cooperation is also aimed at intensifying research and development activities in the field of so-called clean energy technologies.

There is a consensus among practitioners and theorists that the use and application of the latest digital technologies will enable a more efficient use of energy resources and positively affect all pillars of the energy triangle-energy security, economic growth, and sustainability $[6,21]$. 
Energy security can be greatly enhanced by technologies that control the system and improve its stability. Digitalization is mainly based on technology that captures, transmits, and analyzes data that can then be used. With the increasing number of decentralized, variable power generators, the system must receive technological support to cope with this complexity, high rate of variability in power generation, and maintain balance. Information technologies for system balance control (the so-called "smart grid") provide information about actual and predicted demand, production, and network capacity [47,48]. Processing such a large amount of different information also enables faster fault detection and even remote fault resolution in the system.

Digital technologies also foster cost reduction, and this is a feature of most digital applications, regardless of their classification. Data analytics and machine learning in particular can optimize internal processes and increase predictive capabilities by creating digital twins. [49]. With usage of RPA, many repetitive tasks can be automated and connected to the information systems of all links in the supply chain their [50]. This all leads to increased process and system-wide efficiency.

Digital technologies also favor sustainability as they help to: (i) reduce energy demand, and thereby diminish greenhouse gas emissions and resource consumption (ii) through more accurate demand forecast to adjust supply and hence optimize energy production, (iii) avoiding unnecessary network reinforcements.

Last but not least, digitalization drives decentralizing of the energy system. The continuous decline in the cost of distributed energy resources (DER) and the pressure to contain adverse climate change are forcing investment in renewable energy and energy storage. Digitalization will enable gradually transform and integrate local, independently produced energy. Investing in a mix of renewable and distributed energy resources (such as solar photovoltaics), energy storage, electric mobility, combined heat and power, energy management systems, and smart appliances means radically increasing the connections between new devices and their producers, distributors, and users. For example, with the electrification of the heating and transport sector, billions of internet-connected DER devices are expected to integrate with existing electrical grids by 2030 [28]. Only the use of advanced digital technologies will allow the integration and management of such a decentralized system.

\subsubsection{Micro-Economic Drivers of Business Digitalization in the Energy Sector}

Many companies in the energy sector recognize the potential of digital technologies and feel an urgent need to "become digital" [26], as it serves as an opportunity to gain direct economic benefits. These are primarily related to the possibility of revenue growth through the development of new products, services, and access to new customers.

An important driver is also to better satisfy customers' needs and expectations, which will provide a competitive advantage. For decades, customers wanted electricity to be cheap and accessible. Nowadays, customers and consumers from highly developed countries have increased their expectations towards this commodity. Climate-friendly energy and transparency regarding its consumption and costs have become more important. Digital applications in the form of 'smart meters' or 'smart home' more broadly, can help to meet the expectations of reduced costs and increased transparency and use of renewable energy [29]. The 'smart home' concept allows the measurement of energy consumption on daily basis, and issuing billing accordingly, as well as showing the consumption of individual household appliances and visualize the information. This creates transparency, and provides the opportunity to identify energy saving potential. Usage of neural networks in such systems helps to adapt to the habits of consumers. These systems increase customer satisfaction on the one hand and reduce costs on the other, as most interactions can be performed by online consumers' portals. 


\subsection{Inequalities in Sustainable Energy and Digitalization in European Countries}

The transformation of the European energy sector takes place at different levels. On the one hand there is a common, unified regional policy where the objectives described above are set, negotiated, and approved, while (e.g., with regard to nuclear policy, priorities and pace of legal, infrastructural and process changes along the supply chain, the choice of renewable sources, administrative regulations, etc.). Its formation and implementation is decentralized, politicized, and depends on the individual policies of Member States [51-55].

The reduction effort targets for individual countries were differentiated by setting annual greenhouse gas emission caps based on EU members national GDP per capita. However, this differentiation does not mean that every member state will be able to meet the adopted targets, as GDP per capita provides information on the level and rate of growth of the economy to date, but does not reflect what percentage of this growth is generated with worn-out energy infrastructure requiring investment. GDP per capita only indirectly suggests the capital potential and the size of possible outlays for transforming the energy sector. The economic policy priorities of the Member States take into account many other (separate from energy) areas of social and economic life and, depending on these (actual/not publicly declared) priorities, available resources are redistributed.

If these results (in terms of the use of RES) vary so considerably (see Figure 1), perhaps some states have placed more emphasis on strengthening the stability or efficiency of the sector, further fulfilling environmental requirements?

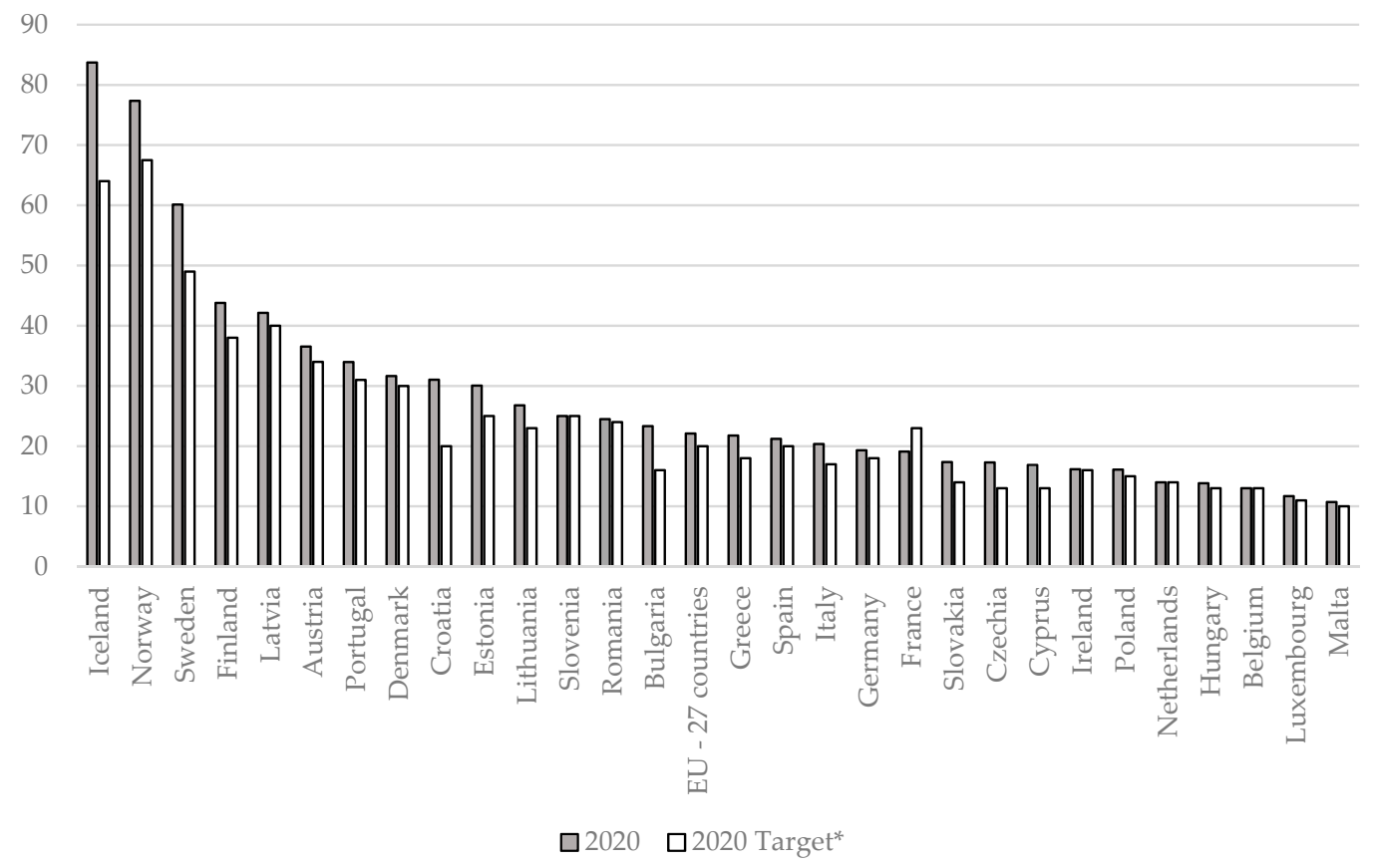

Figure 1. Share of energy from renewable sources, 2020 (\% of gross final energy consumption). Source: Own elaboration based on [56,57]. * These targets are set in Directive 2009/28/EC on the promotion of the use of energy from renewable sources.

To answer this question, it is worth taking into account the following relationships. Firstly, an increase in the use of RES is associated with an increase and dispersion of investments in prosumer energy production. There are environmental (but also technical and economic) benefits of integrating many small units producing energy from different renewable sources into the system. However, the energy system thus constructed becomes increasingly complex [58-60]. For such a system to work efficiently, it is necessary to harness digital technologies to monitor and manage it, allowing for direct energy transmission between small energy producers and their consumers, storage of this energy, seamless billing, ensuring flexible transmission, dynamic price planning, etc. 
The use of renewable sources in the energy production structure in Poland is only 16\% in the total energy production. Energy production in Poland is mainly based on hard coal and lignite. The third largest energy source is crude oil. Moreover, more than $50 \%$ of energy production facilities are over 30 years old. In addition, according to research by Śleszyński et al. [61], Poland is characterized by a dispersed settlement structure and diverse regional development, which further increases the cost of energy transmission. The latter aspect may explain the different speed of adjustment to the general (not only environmental) requirements of EU policy within the Visegrád countries. The study of Wach et al. [51] shows that, despite the fact that the entire Visegrád group (Poland, the Czech Republic, Slovakia, and Hungary) are heavily dependent on coal energy sourcing, the effectiveness of the implementation of the EU energy policy is lowest in Poland, while the Czech Republic, Hungary, and Slovakia almost achieved the goals during the study period (2005-2018).

Delays in the energy transition in EU countries are usually accompanied by delays in the digitalization of the economy and society. Poland ranks 24th of 27 EU Member States in the 2021 edition of the Digital Economy and Society Index [62]. It is ahead only of Greece, Bulgaria, and Romania (see Figure 2). Its score of 41 points is lower than the EU average, which is 50.7. Other central European countries, such as Hungary, Slovakia, and the Czech Republic, also have digitalization rates below the EU average.

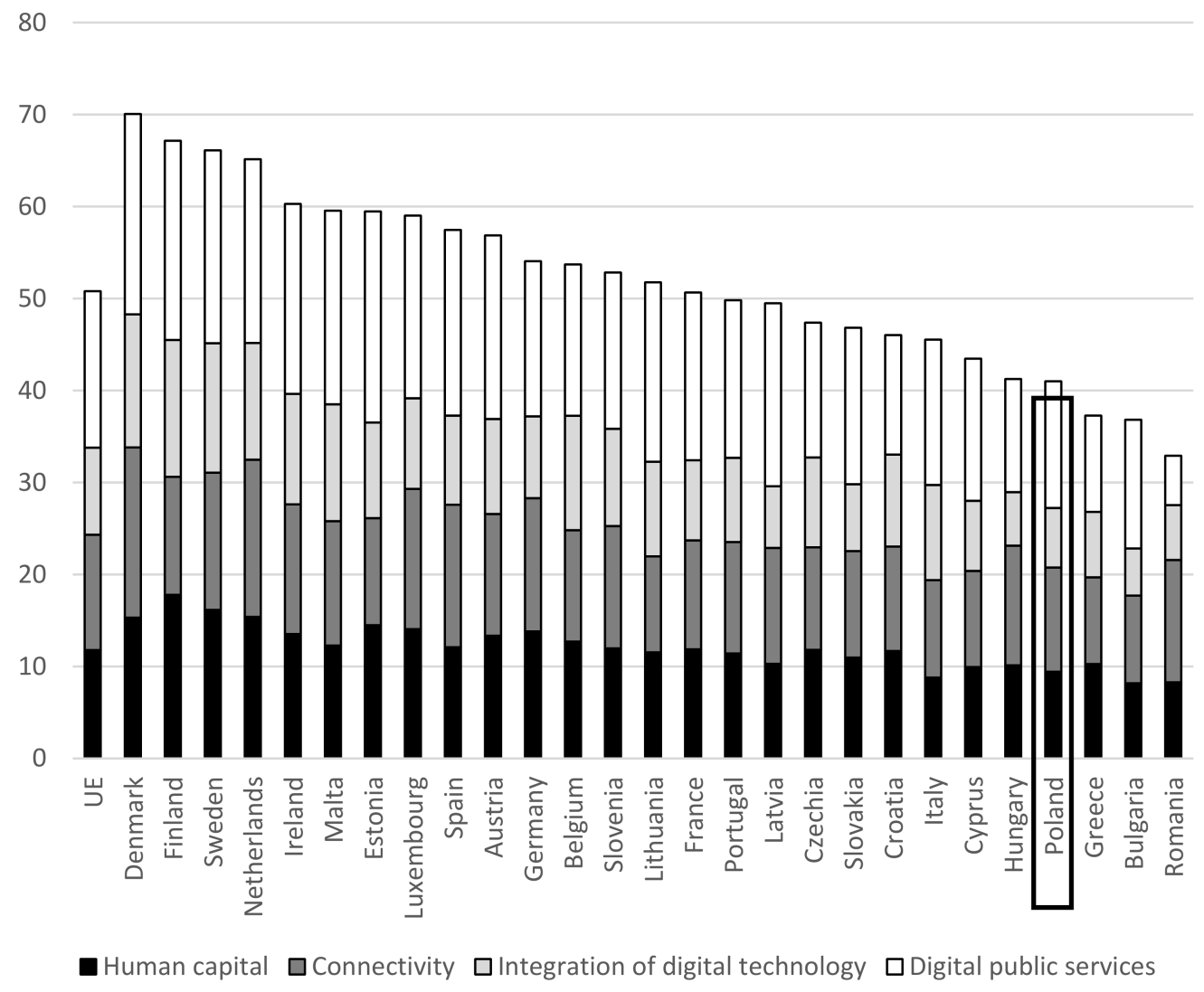

Figure 2. Poland in the ranking of the Digital Economy and Society Index (DESI). Source: Own elaboration based on [62].

Only 52\% of Polish SMEs have achieved at least a basic level of the digital indicator, which is below the EU average of $60 \%$, and $60 \%$ of enterprises have achieved a medium/high level of the ICT indicator (digital level for environmental sustainability), which is which is below the EU average of $66 \%$. Overall, $15 \%$ of Polish enterprises use cloud solutions, compared to the EU average of $26 \%$, and $18 \%$ use some kind of artificial intelligence (AI) technology in their activities (EU average-25\%). Only 14\% of Polish enterprises actively use social media, and 29\% engage in electronic information exchange [62]. E-invoicing and big data are also not yet widespread. 
The situation of the Polish energy sector against the above-mentioned EU commitments in this area looks extremely unfavorable; the way to meet them will require a number of socially unpopular actions (e.g., mine closures) and comprehensive investments in infrastructure and technology, including digital ones. To meet the EU requirements, Poland's energy policy until 2040 is based on three pillars [63]:

- fair energy transition; this aims at transforming coal regions, reducing energy poverty in regions and households and developing new industries related to RES and nuclear energy;

- a zero-carbon energy system; the aim is to reduce the share of coal in electricity generation to $56 \%$ by 2030 . To meet this target, the share of RES in gross final energy consumption is planned to increase to $23 \%$, with $32 \%$ of RES to be used in electricity (mainly through wind and photovoltaic sourcing), 28\% in district heating and 14\% in transport (use of electro-mobility);

- $\quad$ good air quality; this policy is focused on combating smog with strong use of digital technologies enabling energy storage, roll-out of smart metering, energy management and enhancing electro-mobility.

According to the described policy assumptions, approximately EUR 58 billion will be allocated to the national energy-climate transformation until 2030, with sources coming from EU, international and national budgets. As clearly stated in PEP2040, the top national priority is energy security, combined with increased energy efficiency and reduced environmental impact. Within the implementation of the above mentioned three pillars, eight specific objectives were specified:

1. Optimal use of own energy resources, referring above all to the transformation of coal regions;

2. Development of electricity generation and grid infrastructure: based on the creation of a reasonably independent capacity market and the implementation of smart grids;

3. Diversification of supplies and expansion of network infrastructure for natural gas, crude oil and liquid fuels. The Baltic Pipe and the Pomeranian Pipeline are planned to be built;

4. Development of energy markets through construction of a gas hub and development of electro-mobility;

5. Implementation of nuclear energy;

6. Development of renewable energy sources: through the implementation of an offshore wind program and greater use of biomass, biogas, and geothermal energy;

7. Development of district heating and cogeneration;

8. Improving energy efficiency; through the implementation of digital technologies, promotion, increasing electro-mobility and providing efficient and environmentally friendly access to heating.

An analysis of the assumptions of the discussed policy indicates that some of the projects (especially those concerning the transformation of coal regions, the creation of new infrastructure of storage hubs, new transmission lines of international character, the increase in electro-mobility, and the integration of heat policy) are to be coordinated at the governmental level, and are not specifically assigned to the tasks of existing links in the energy value chain. Objectives directly related to these links relate mainly to the efficiency increase and securing stability of the system. Meeting environmental requirements appears as an externally imposed necessity that must be addressed. Lastly, let us not forget that, in catching up economies, priorities related to the pursuit of environmental protection and sustainable development often give way to economic and social goals [64-69]. All of this leads to the assumption that at the managerial level, in a country such as Poland, the main driver of the sector's transformation (general and digital) will be economic considerations. 


\subsection{Barriers to Digitalization and Energy Transition}

The application of digital technologies, not only in the energy sector, involves a number of challenges [70-73]. From a managerial point of view, the first and foremost is the need to have a suitably qualified workforce with the knowledge and competences to use and innovatively develop the technologies in question [21]. The knowledge and skills should be possessed by those employed in all links (albeit in varying degrees) and at all stages of the energy value chain: designing, forecasting, producing, transmitting, selling, and using energy $[15,74]$. Another requirement is a managerial vision, backed by skills and knowledge of managing and developing such digital-based energy systems [26,75,76]. An obvious requirement is also the capital needed to invest in the purchase, implementation, and use of such technologies.

Digital transformation forces organizational, process, and technology transformation. Such changes are often met with resistance at different levels of management. For companies that cannot grow without continuous transformation, an indispensable managerial skill is change management, where overcoming employee resistance is a central aspect [77].

Even if such barriers or requirements are met from the point of view of enterprises and the need to implement them is justified, prioritized, and feasible, difficulties in the application and use of digital technology may arise from external conditions. The deployment and use of digital technology can be hampered or restricted by governmental limitation of investments in this area (e.g., due to redirection of investments to other spheres of economic or social life), or resistance of social groups and certain economic entities interested in maintaining the status quo in terms of the structure and functioning of the existing energy sector.

The fast and effective implementation of digital technologies in this sector also requires the support of the government and consent of social groups so far associated with the energy sector, with full awareness that the sector transformation will involve the need for layoffs. In the face of the digital revolution, national and regional governments are increasingly defining digitalization as a strategic priority and launching large-scale initiatives to support the digital transformation of science, industry, and society. Poland invests in digital technologies through EU-coordinated programs, and is a member of the European High Performance Computing Joint Undertaking (EuroHPC JU). It also participates in PRACE (Partnership for Advanced Computing in Europe) and the PIONIER-LAB National Platform for Integration of Research Infrastructures. In December 2020, the Council of Ministers adopted the Polish national AI strategy, an entitled Policy for the development of artificial intelligence in Poland from 2020 (Resolution No. 196 of The Council of Ministers of 28 December 2020), which discusses AI developments in six areas: society, education, science, business, public affairs, and international relations.

Despite the measures indicated, it can be assumed that government policy, both in terms of digitalization and energy, may be perceived by Polish energy companies as insufficient, thus constituting a barrier to the digital transformation of companies.

\subsection{Conceptual Framework and Research Propositions}

The above discussion points to three important aspects: (i) the objectives of digitalization of the energy sector at the microeconomic level centered around the energy triangle, (ii) the drivers of digitalization at the company level, and (iii) the factors that are barriers to the transformation process in the energy sector.

With these considerations in mind, the Figure 3 presents the conceptual framework supplemented, with propositions stemming from it.

P1. Supporting environmental protection is a necessary condition for achieving the expected effects of digitalization in the energy industry.

P2. Technological support of prosumers and consumers is a necessary condition for achieving the expected effects of digitalization in the energy sector. 
P3. Higher performance in the energy sector is a necessary condition for achieving the expected effects of digitalization in the energy sector in Poland, a country considered as a catching up economy.

P4. Rapid deployment of new technologies is a necessary condition for achieving the expected effects of digitalization in the energy sector.

P5. The absence of management and external barriers is a necessary condition for the effects of digitalization of the energy sector.

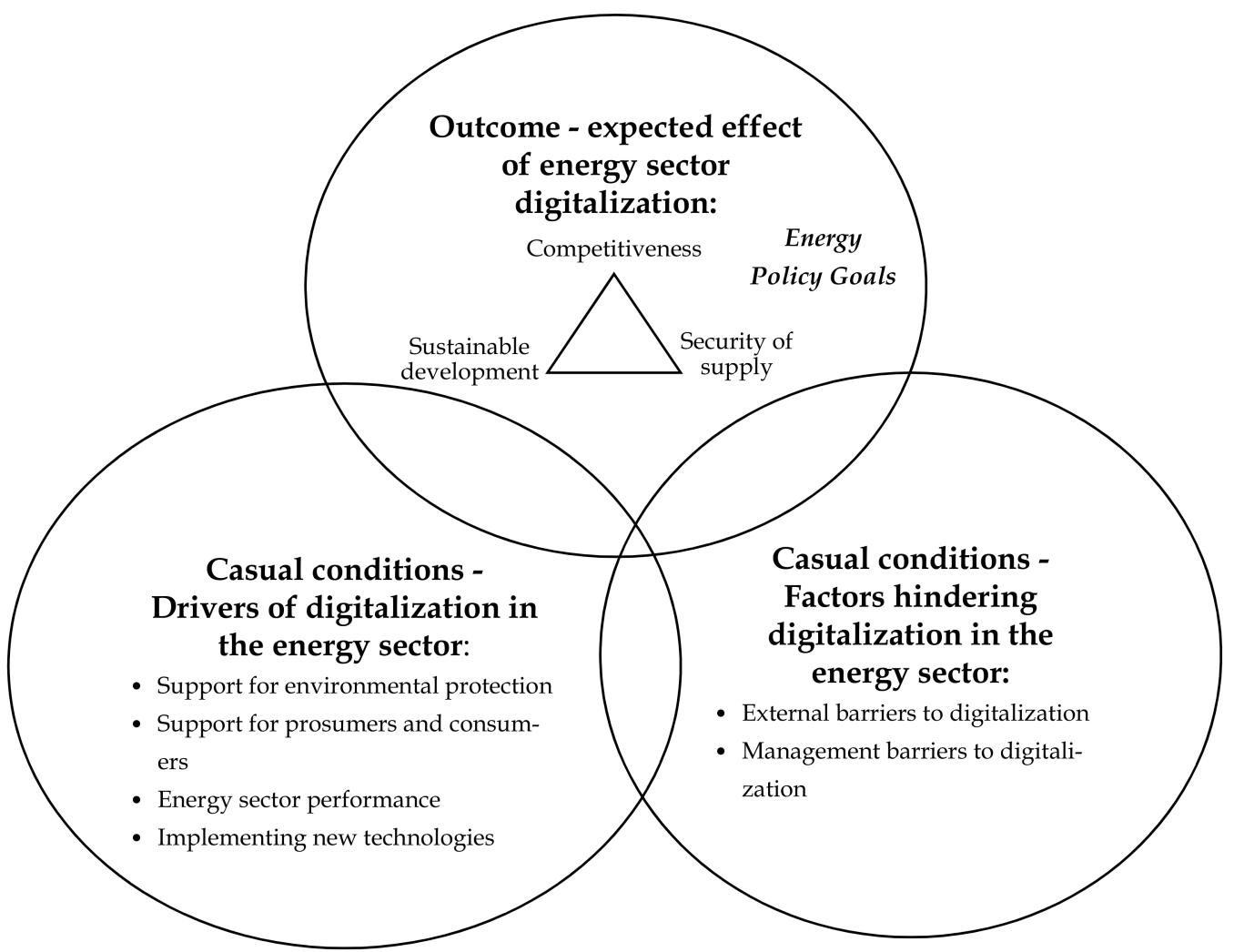

Figure 3. Conceptual framework-drivers and barriers of digitalization in the energy sector. Source: own elaboration.

\section{Research Method}

\subsection{Data Collection}

The sample for this study was collected in October and November 2021. Respondents were experienced managers in the energy industry in Poland. Before sending the questionnaire, we consulted its content with three energy sector experts from the Polish Electricity Industry Association [78] (https:/ / psbe.org.pl) and from the Renewable Energy Association [79]) to minimize misinterpretation or misunderstanding of the questionnaire content. After e-questionnaire revision, we sent it via mail to the one hundred top managers from energy sectors selected from Kompass database [80]. We obtained 44 fully completed responses. Respondents represent different segments of the energy sector. Most of them were associated with the energy generation (17) and energy distribution segments (11). In addition, the sample included representatives from the trading (8), energy transmission (2), and repairs sectors (2). In addition, two managers represented companies involved in the entire energy value chain (i.e., generation, trading, and distribution of energy). Most of the managers came from companies with state or municipal ownership (23). Fully private companies were represented by 12 managers, including eight companies with foreign capital. The sample included top and middle level managers. In total, 10 managers served as CEO or sat on the company's board of directors. The same number each held a marketing or sales manager position and a technical manager position. The sample also included 
financial managers (4), risk managers (4), HR managers (4), and IT managers (2). The characteristics of the sample are shown in Table 2.

Table 2. Characteristics of the research sample.

\begin{tabular}{|c|c|c|c|}
\hline & Differentiation Criteria & Frequency & Percentage \\
\hline \multirow{6}{*}{$\begin{array}{l}\text { Energy industry } \\
\text { segment }\end{array}$} & Energy generation & 17 & 39 \\
\hline & Distribution & 11 & 25 \\
\hline & Trading & 8 & 18 \\
\hline & Energy transmission & 4 & 9 \\
\hline & Repairs in the power industry & 2 & 5 \\
\hline & Energy generation, trading, distribution & 2 & 5 \\
\hline \multirow{4}{*}{$\begin{array}{l}\text { Form of company } \\
\text { ownership }\end{array}$} & $\begin{array}{l}\text { Company with participation of the } \\
\text { State Treasury }\end{array}$ & 22 & 50 \\
\hline & Company with municipal shareholding & 10 & 23 \\
\hline & $\begin{array}{l}\text { Private ownership with the majority of } \\
\text { foreign capital }\end{array}$ & 8 & 18 \\
\hline & $\begin{array}{l}\text { Private ownership with majority of } \\
\text { Polish capital }\end{array}$ & 4 & 9 \\
\hline \multirow{7}{*}{$\begin{array}{l}\text { Professional } \\
\text { position }\end{array}$} & Sales or marketing manager & 10 & 23 \\
\hline & $\begin{array}{l}\text { Manager in technical areas (production, } \\
\text { technology, etc.) }\end{array}$ & 10 & 23 \\
\hline & CEO or member of the board of directors & 10 & 23 \\
\hline & Finance manager & 4 & 9 \\
\hline & $\begin{array}{l}\text { Manager with responsibility for } \\
\text { risk management }\end{array}$ & 4 & 9 \\
\hline & Human resources manager & 4 & 9 \\
\hline & IT manager & 2 & 5 \\
\hline
\end{tabular}

Source: own elaboration.

\subsection{Method of Analyzing Data}

The data were analyzed using fuzzy set Qualitative Comparative Analysis (fsQCA). This method uses a configuration approach, fuzzy set theory, and Boolean minimization to determine what combinations of case characteristics may be necessary or sufficient to produce a result [81], and is therefore suitable for research of small size samples. It allows for the analysis of relationships between antecedents and outcomes in a causal and configurational manner. The strengths of fsQCA include: (1) revealing causal complexity, (2) presenting results as paths of conditioning antecedents, (3) identifying necessary conditions, (4) the possibility to calibrate fuzzy sets of qualitative data in a transparent manner, (5) studying the sub- set relations, and (6) identifying a set of both necessary and sufficient conditions that lead to the outcome. Weaknesses include: (1) the way of calibrating interview data is left to the researcher's choice, (2) quantification and prediction is limited, mainly due to the small sample size, and (3) unidirectionality.

Due to its undeniable benefits, social sciences have started using fsQCA method increasingly in the last few years [82,83]. In this study, the fsQCA model was used to test the formulated propositions by assessing the extent to which six identified factors driving or hindering (causal conditions) the achievement of the expected effects of digitalization in the energy sector in Poland (outcome). The identified factors (positively influencing the effects of digitalization of the energy sector covering the so-called energy triangle) are support for environmental protection, support for prosumer/consumer activity, obtaining higher results in the energy sector, and implementation of new technologies. Causes of delay in the achievement of the expected results of the energy sector digitalization are external barriers (state policy, social resistance, cooperators' mentality, etc.) and management barriers (lack of vision or leadership, insufficient competence of employees, outdated infrastructure, unwillingness to cooperate, etc.). It sought to understand what drivers of energy digitalization are important for managers and what sort of barriers hinder energy digitalization. 
The descriptive statistics for the four positive and two negative conditions and the outcome are presented in Table 3 based on the scores assigned by the respondents using the original five-point Likert type scale. The aggregated variables (each summed scale) used in the study were validated for unidimensionality and reliability. Exploratory factor analysis was used to check unidimensionality. Cronbach's alpha internal consistency measure was used to ensure reliability. The analyses indicate acceptable reliability coefficients $(\mathrm{CA}>0.70)$ and unidimensionality of all variables (loadings $>0.70$ ).

Table 3. Scale items with mean, standard deviation, and standardized loading.

\begin{tabular}{|c|c|c|c|c|}
\hline & Construct and Scale Items & Mean & S.D. & Loading \\
\hline \multicolumn{5}{|c|}{$\begin{array}{l}\text { Technological support for prosumers and consumers } \\
\text { (SupProCo) } \mathrm{CA}=0.93 \text { ) }\end{array}$} \\
\hline 1. & $\begin{array}{l}\text { Digitalization will make it easier to lease } \\
\text { energy storage }\end{array}$ & 3.95 & 0.78 & 0.82 \\
\hline 2. & $\begin{array}{l}\text { Digitalization will facilitate digital energy } \\
\text { disposition services }\end{array}$ & 4.27 & 0.83 & 0.80 \\
\hline 3. & $\begin{array}{l}\text { Digitalization of the energy sector will support the use } \\
\text { of energy-efficient equipment for home or business use }\end{array}$ & 3.91 & 0.92 & 0.78 \\
\hline 4. & $\begin{array}{l}\text { Digitalization will facilitate the offering or transition to } \\
\text { a flexible consumer pricing model }\end{array}$ & 4.55 & 0.80 & 0.76 \\
\hline 5. & $\begin{array}{l}\text { Digitalization will greatly expand the offering of } \\
\text { services directly to consumers (e.g., home energy } \\
\text { installations such as solar panels) }\end{array}$ & 4.09 & 0.87 & 0.76 \\
\hline 6. & $\begin{array}{l}\text { Digitalization will make it possible to expand service } \\
\text { offerings and better meet customer needs }\end{array}$ & 4.50 & 0.74 & 0.75 \\
\hline \multicolumn{5}{|c|}{$\begin{array}{l}\text { Support for environmental protection (SupEnv) } \\
(C A=0.93)\end{array}$} \\
\hline 1. & $\begin{array}{l}\text { Digitalization will contribute to reducing emissions or } \\
\text { waste in the energy sector }\end{array}$ & 3.41 & 1.10 & 0.95 \\
\hline 2. & $\begin{array}{l}\text { Digitalization will facilitate the shift away from certain } \\
\text { environmentally harmful energy sources }\end{array}$ & 3.36 & 1.18 & 0.84 \\
\hline 3. & $\begin{array}{l}\text { Digitalization will facilitate switching of energy } \\
\text { sources and contribute to environmental protection }\end{array}$ & 3.86 & 0.94 & 0.81 \\
\hline 4. & $\begin{array}{l}\text { Digitalization will ensure the integration of new } \\
\text { energy sources }\end{array}$ & 4.00 & 0.82 & 0.72 \\
\hline 5. & $\begin{array}{l}\text { Digitalization will increase the stability of the } \\
\text { energy system }\end{array}$ & 3.50 & 0.96 & 0.72 \\
\hline \multicolumn{5}{|c|}{ Energy sector performance $($ SecPerf) $(\mathrm{CA}=0.92)$} \\
\hline 1. & $\begin{array}{l}\text { Digitalization will primarily contribute to increased } \\
\text { operational efficiency }\end{array}$ & 4.09 & 1.02 & 0.81 \\
\hline 2. & $\begin{array}{l}\text { Digitalization will allow a noticeable increase } \\
\text { in revenues }\end{array}$ & 4.23 & 1.02 & 0.71 \\
\hline 3. & $\begin{array}{l}\text { Digitalization will enable significant cost reductions in } \\
\text { the sector }\end{array}$ & 3.95 & 0.95 & 0.70 \\
\hline \multicolumn{5}{|c|}{ Implementing new technologies (NewTech) $(\mathrm{CA}=0.83)$} \\
\hline 1. & Cloud Computing & 3.77 & 0.92 & 0.84 \\
\hline 2. & Machine learning & 3.36 & 0.73 & 0.82 \\
\hline 3. & Blockchain & 3.05 & 0.72 & 0.74 \\
\hline 4. & Robotic Process Automation (RPA) & 3.05 & 0.95 & 0.64 \\
\hline
\end{tabular}


Table 3. Cont.

\begin{tabular}{|c|c|c|c|c|}
\hline & Construct and Scale Items & Mean & S.D. & Loading \\
\hline \multicolumn{5}{|c|}{ External barriers to digitalization $($ ExtBar $)(C A=0.93)$} \\
\hline 1. & Other government priorities (energy policy) & 3.00 & 1.19 & 0.94 \\
\hline 2. & $\begin{array}{l}\text { Blurry institutional framework hampering sector's } \\
\text { strategic transformation }\end{array}$ & 2.73 & 0.93 & 0.93 \\
\hline 3. & $\begin{array}{l}\text { Lack of mental readiness for such implementations } \\
\text { from suppliers or consumers }\end{array}$ & 3.14 & 0.94 & 0.84 \\
\hline 4. & $\begin{array}{l}\text { Resistance of social groups employed or connected } \\
\text { with coal mines }\end{array}$ & 3.18 & 1.14 & 0.84 \\
\hline \multicolumn{5}{|c|}{$\begin{array}{l}\text { Management barriers to digitalization (Mngt Bar) } \\
(\mathrm{CA}=0.89)\end{array}$} \\
\hline 1. & $\begin{array}{l}\text { Lack of appropriate competences or insufficient } \\
\text { training of employees }\end{array}$ & 3.41 & 0.91 & 0.91 \\
\hline 2. & $\begin{array}{l}\text { Outdated infrastructure not compatible with } \\
\text { new technologies }\end{array}$ & 3.59 & 1.10 & 0.87 \\
\hline 3. & Lack of leadership or vision & 3.09 & 0.92 & 0.79 \\
\hline 4. & Lack of money for digital investment & 3.45 & 1.01 & 0.74 \\
\hline 5. & $\begin{array}{l}\text { Lack of agreement or cooperation between actors in } \\
\text { the network }\end{array}$ & 3.09 & 0.97 & 0.71 \\
\hline \multicolumn{5}{|c|}{ Effects of digitalization (EfectDig) $(C A=0.93)$} \\
\hline 1. & $\begin{array}{l}\text { Digitalization will contribute most to energy security } \\
\text { (including system stability). }\end{array}$ & 3.05 & 1.046 & 0.92 \\
\hline 2. & $\begin{array}{l}\text { Digitalization will contribute to the greatest extent to } \\
\text { increased sustainability (including, e.g., } \\
\text { decarbonization, increased share of renewable energy } \\
\text { sources and optimization of energy consumption). }\end{array}$ & 3.05 & 1.214 & 0.86 \\
\hline 3. & $\begin{array}{l}\text { Digitalization will make the greatest contribution to } \\
\text { achieving or maintaining competitiveness in the } \\
\text { energy sector. }\end{array}$ & 3.86 & 1.167 & 0.74 \\
\hline
\end{tabular}

\subsection{Calibration}

In fsQCA, we can use continuous or interval scale variables, which must first be calibrated to be transformed into fuzzy categories or variables. First, all variables are transformed into sets that reflect the degree to which a variable belongs to a particular category. The sets can take any value between 0 and 1 [81]. All calibrated values show the degree of membership of the set, where 0 indicates complete lack of membership and 1 indicates full membership. The variables in the set are calibrated with fuzzy values (the variables take different degrees of membership ranging from 0 to 1). Fuzzy set analysis most commonly uses three calibration limits: 0.05 as the threshold for non-membership, 0.50 as the breakpoint for maximum ambiguity, and 0.95 as the threshold for full set membership [84,85]. FS/QCA 3.0 software [86] was used to conduct the analysis in this study. For five-point Likert scales, previous studies suggest that values of 4, 3, and 2 can be used as thresholds [87] for fuzzy sets. This approach was used in the calibration of the variables in this research.

\section{Results}

\subsection{Truth Table}

The fsQSA involves several steps [85]. The first one regards constructing a truth table containing all possible configurations with $2^{\mathrm{k}}$ rows, where $\mathrm{k}$ is the number of conditions (outcome predictors). In this case, the number of configurations is 64 . A value of 1 indicates a fuzzy set membership score of 0.5 or higher, and 0 a score below 0.5 . The "number" 
column shows the number of cases that exhibit the listed configuration. A frequency of zero means that none of the cases in the sample adopt the given configuration of causal conditions. In this study, due to the relatively small sample size, the frequency threshold was set to 2. After removing combinations with zero and 1 frequency (so-called logical remainders), the truth table was sorted according to raw consistency where the minimum recommended threshold value is 0.75 [88]. The FsQCA software also calculates PRI (Proportional Reduction in Inconsistency) consistency relevant only for fuzzy sets. It is used to avoid simultaneous relations of subsets of configurations for both the outcomes of result and no result. PRI consistency scores should be high and close to raw consistency scores. Configurations with PRI scores below 0.5 indicate significant inconsistency [87]. In the analysis conducted, this condition was met by taking a raw consistency threshold of 0.831 . Configurations with raw consistency values below 0.831 and PRI consistency below 0.5 were assigned a value of zero (see Table 4 ).

Table 4. fsQCA results: truth table.

\begin{tabular}{|c|c|c|c|c|c|c|c|c|c|c|}
\hline SupProCo & SupEnv & SecPerf & NewTech & ExtBar & MngtBar & Number & EfectDig & $\begin{array}{c}\text { Raw } \\
\text { Consistency }\end{array}$ & $\begin{array}{c}\text { PRI } \\
\text { Coherence }\end{array}$ & $\begin{array}{c}\text { SYM } \\
\text { Consistency }\end{array}$ \\
\hline 1 & 0 & 1 & 0 & 1 & 0 & 2 & 1 & 0.977 & 0.954 & 0.954 \\
\hline 1 & 0 & 1 & 1 & 0 & 0 & 2 & 1 & 0.964 & 0.923 & 0.960 \\
\hline 1 & 1 & 1 & 1 & 0 & 0 & 8 & 1 & 0.891 & 0.857 & 0.857 \\
\hline 1 & 1 & 1 & 0 & 1 & 1 & 8 & 1 & 0.885 & 0.695 & 0.872 \\
\hline 1 & 1 & 1 & 1 & 0 & 1 & 4 & 1 & 0.842 & 0.743 & 0.743 \\
\hline 1 & 1 & 1 & 1 & 1 & 1 & 6 & 1 & 0.831 & 0.728 & 0.728 \\
\hline 1 & 0 & 1 & 1 & 0 & 1 & 4 & 0 & 0.683 & 0.308 & 0.308 \\
\hline 1 & 1 & 0 & 1 & 1 & 1 & 2 & 0 & 0.438 & 0.020 & 0.020 \\
\hline 0 & 0 & 0 & 0 & 1 & 1 & 2 & 0 & 0.369 & 0 & 0 \\
\hline
\end{tabular}

Source: own research.

\subsection{Analysis of Necessary Conditions}

The necessary conditions analysis determines whether some of the conditions are indispensable for the outcome, i.e., the expected effects of digitalization of the energy sector. A condition is necessary if all cases that exhibit the condition also exhibit the outcome and there are no cases that exhibit the outcome and do not exhibit the condition. A condition is considered necessary if its consistency is greater than 0.9 [89] (p. 143). Consistency measures how well the empirical evidence supports the existence of a relationship between configuration and outcome [90]. Table 5 presents an analysis of the necessary conditions both with and without the presence of a condition.

Table 5. Analysis of necessary conditions.

\begin{tabular}{ccc}
\hline Outcome Variable: EfectDigc & Consistency & Coverage \\
\hline SupProCo & $\mathbf{0 . 9 6 0}$ & 0.661 \\
$\sim$ SupProCo & 0.075 & 0.550 \\
SupEnv & 0.839 & 0.746 \\
$\sim$ SupEnv & 0.297 & 0.639 \\
SecPerf & $\mathbf{0 . 9 8 2}$ & 0.720 \\
$\sim$ SupProCo & 0.075 & 0.550 \\
NewTech & 0.714 & 0.720 \\
NewTech & 0.431 & 0.722 \\
ExtBar & 0.512 & 0.630 \\
$\sim$ ExtBar & 0.621 & 0.800 \\
MngtBar & 0.596 & 0.579 \\
$\sim$ MngtBar & 0.503 & 0.899 \\
\hline
\end{tabular}

Source: own research.

In this case, two conditions: prosumer/consumer support (SupProCo, consistency $=0.96$ ) and sector performance (SecPerf, consistency $=0.98$ ) are necessary, which means that in all configurations leading to an outcome these two conditions are present. The 
analysis of the necessary conditions shows at the same time the results for the five formulated propositions. The analysis suggests that propositions 2 and 3 are supported, while propositions 1, 4, and 5 are not. Rapid deployment of new technologies and support for environmental protection are not necessary conditions for the expected effects of digitalization of the energy sector. Similarly, the absence of external and managerial barriers are also not necessary conditions for the effects of digitalization in the energy sector.

\subsection{Analysis of Sufficient Conditions}

The fsQCA methodology also provides an analysis of sufficient conditions. According to Schneider and Wagemann [89], a condition is sufficient for an outcome if all cases exhibiting the condition also exhibit the outcome, but there are also cases that exhibit the outcome but do not exhibit the condition. The model used in this analysis contains six conditions:

\section{EfectDig = f(SupProCo, SupEnv, SecPerf, NewTech, ExtBar, MngtBar)}

The fsQCA method allows for the analysis of combinations, or configurations of conditions that lead to an outcome; in the case of this research, the expected effects of the digitalization of the energy sector.

The next step uses an algorithm based on Boolean algebra to simplify the truth table. The resulting intermediate solution consists of three combinations that are sufficient to achieve expected effects of digitalization in energy sector. The complex and parsimonious solutions can be considered as the two ends of the complexity-parsimony continuum. The intermediate solutions use only a subset of the simplifying assumptions that are used in the most parsimonious solution (Table 6).

Table 6. fsQCA results: intermediate solution leading to effects of digitalization.

\begin{tabular}{lccc}
\hline \multicolumn{1}{c}{ Configurations } & $\begin{array}{c}\text { Raw } \\
\text { Coverage }\end{array}$ & $\begin{array}{c}\text { Unique } \\
\text { Coverage }\end{array}$ & Consistency \\
\hline SupProCo*SupEnv ${ }^{*}$ SecPerf & 0.812 & 0.435 & 0.791 \\
SupProCo*SecPerf* $\sim$ ExtBar* MngtBar & 0.384 & 0.056 & 0.897 \\
SupProCo*SecPerf* $\sim$ NewTech $\sim$ MngtBar & 0.264 & 0.034 & 0.874 \\
Coverage for the entire solution: 0.902 & & & \\
Consistency for the total solution: 0.804 & & & \\
Notes: ${ }^{*}$, logical AND; $\sim$, logical negation. Source: own research. & &
\end{tabular}

The results presented in Table 6 suggest three effective combinations for high expected effects of digitalization in energy sector. In detail, the combination of high support for prosumers/consumers with high support for environmental protection, together with high energy sector performance, leads to high expected effects of digitalization in energy sector regardless of rapid implementation of new technologies in the sector (solution 1). High effects of digitalization are also expected without support for environmental protection in the combination of high support for prosumer/consumer activity with high sectoral performance with the absence of external and managerial barriers (solution 2). This combination also ignores the need for rapid deployment of new technologies to energy companies. The last combination (solution 3 ) is the most surprising, as it includes the absence of rapid deployment of new technologies in addition to high support for prosumers/consumers, together with high sector performance and the absence of management barriers. As can be observed, the previously identified necessary conditions, i.e., prosumer/consumer support and high sector performance, are present in all solutions leading to the outcome.

The relevance of the indicated combinations of causal conditions depends on the extent to which they explain the outcome and the extent to which they characterize most of the analyzed cases. In the first case, the consistency indicator is relevant, while in the second case, the coverage parameter is important [85]. In the presented analysis, both consistency and coverage are satisfactory at 0.80 and 0.90 , respectively. This means that the 
three configurations indicated above are sufficient to achieve high digitalization effects in $80 \%$ of cases and coverage $90 \%$ of cases.

The results of the fsQCA can also be presented as a combination of both parsimonious and intermediate solutions [84]. The parsimony set of solutions represents the most important conditions that cannot be omitted from any solution. As prime conditions [91], they are automatically detected by fsQCA. The parsimony solution in this study indicated the following core conditions: $\sim$ MngtBar + SupEnv*SecPerf (see Table 7). This means that the absence of managerial barriers or high environmental protection and high sector performance are key sufficient conditions. This indicates the particular causal importance of these factors for the occurrence of the outcome, i.e., the expected effects of the digitalization of the energy sector.

Table 7. fsQCA results: parsimonious solution leading to effects of digitalization.

\begin{tabular}{lccc}
\multicolumn{1}{c}{ Configurations } & $\begin{array}{c}\text { Raw } \\
\text { Coverage }\end{array}$ & $\begin{array}{c}\text { Unique } \\
\text { Coverage }\end{array}$ & Consistency \\
\hline$\sim$ MngtBar & 0.503 & 0.105 & 0.899 \\
SupEnv*SecPerf & 0.837 & 0.440 & 0.796 \\
Coverage for the entire solution: 0.942969 & & & \\
Consistency for the total solution: 0.807742 & & & \\
\hline Notes: $*$ logical AND $\sim$ logical negation. Source: & & \\
\hline
\end{tabular}

Notes: ${ }^{*}$, logical AND; , logical negation. Source: own research.

Combinations of parsimonious and an intermediate solution are presented in Table 8 . These are referred to as the "core conditions". In contrast, conditions that are eliminated in the parsimony solution and only appear in the intermediate solution are called "peripheral conditions" [91]. Full circles in the table $(\bullet)$ indicate the presence of a given condition, while empty circles (o) indicate its absence. Furthermore, core and peripheral conditions are distinguished by the size of the symbols used. Larger circles indicate core conditions that are part of both the parsimonious and intermediate solution. Smaller circles symbolize complementary conditions that are only present in the intermediate solution.

Table 8. fsQCA results: key and peripheral conditions for achieving effects of digitalization.

\begin{tabular}{lccc}
\hline & Configurations & \multicolumn{3}{c}{ Solutions } \\
\cline { 2 - 4 } & $\mathbf{1}$ & $\mathbf{2}$ & $\mathbf{3}$ \\
\hline SupProCo & $\mathbf{0}$ & $\mathbf{0}$ \\
SupEnv & $\mathbf{1}$ & 0 \\
SecPerf & & & \\
NewTech & & 0 & 0 \\
ExtBar & & 0 & 0.874 \\
MngtBar & 0.791 & 0.897 & 0.812 \\
\hline Consistency & 0.812 & 0.812 & \\
Raw Coverage & 0.804 & & \\
\hline Overall solution consistency: & 0.902 & & \\
Overall solution coverage: & & & \\
\hline
\end{tabular}

Note: Black circles $(\bullet)$ indicate the presence of a condition, empty circles (o) indicate its absence. Larger circles are key conditions; smaller circles are peripheral conditions; empty line- "don't care" condition. Source: own research.

\section{Discussion}

According to the opinions of managers representing the energy sector, the core conditions sufficient for achieving the effects of digitalization of the energy sector (including sustainability, stability, and competitiveness) are a combination of environmental protection efforts together with high performance in the sector. This combination, i.e., the 
simultaneous pursuit of environmental protection and the pursuit of improved sector performance, should guarantee the achievement of high sector digitalization effects. Another core option is the absence of managerial barriers to digitization, covering aspects such as lack of leadership and vision, inadequate staff competencies, outdated infrastructure, lack of money for digitization or, finally, reluctance to network and collaborate in the sector. Management barriers were found to be more important for managers than external ones (such as inconsistent government policies or regulations, social resistance from coal mining communities, or other mentality issues in society).

It seems, therefore, that the sector faces a major challenge related not so much to overcoming external barriers, but to implementing better management focused on the development of digital competencies and extensive cooperation with various network participants.

One of the surprising findings is the lack of high importance of rapid implementation of new technologies into the sector, such as cloud computing, machine learning, blockchain, or robotic process automation (RPA). Even though implementing digital technologies is a primary determinant of digitalization, it turns out that, in the opinion of managers, the implementation of this technology alone does not guarantee the achievement of the expected effects. Moreover, in one of the paths leading to digitalization effects, there is an absence of rapid implementation of new technologies. An explanation for this may be managers' concerns about the industry's adaptation problems with new technologies and their mixed or negative attitudes toward technological change. Technophobia (rejection and/or avoidance of technology), or technophilia (excessive preoccupation with technology) are described as extreme attitudes towards digital technologies [92,93]. In the case of the prevalence of negative emotions towards the implementation of new technologies, technological anxiety seems to be the appropriate term [94]. Another explanation could be the priority placed on the purpose of digitalization rather than the technologies themselves. This, however, may be influenced by insufficient managerial awareness of technology or poor digitization competencies [21] to adequately see the opportunities in terms of improving sector performance, increasing sustainability or ensuring energy stability and security. Ultimately, it is clear that without the implementation of new technologies to digitize the sector, the broader effects of digitalization cannot be expected to emerge.

The results of the analysis also identified the necessary conditions for the effects of the digitalization of the energy sector. These are the support of prosumers and consumers of the energy sector and the pursuit of high performance in the sector. Both conditions were present in the three solutions identified in the intermediate solution, which is the main result of the analysis. This fact should be interpreted as follows: in each case, the expected effects of digitalization of the energy sector are accompanied by support for prosumers and consumers and high sector performance. On the other hand, it does not mean that these conditions are sufficient, i.e., they guarantee the appearance of the expected effects. This interpretation is closely related to the logic of set-theoretic relations. As Schneider and Wagemann [89] (p. 8) point out: "Set-theoretic methods operate on membership scores of elements in sets; causal relations are modeled as subset or superset relations; necessity and sufficiency (...) conditions are at the center of attention. The use of set theory focuses attention on unraveling causally complex patterns in terms of equifinality, conjunctural causation, and asymmetry."

Table 9 summarizes the results for testing the adopted propositions. As indicated above, out of the five proposals, two were adopted concerning the necessary conditions for the expected effects of digitalization of the energy sector to appear. They concern support for prosumers and consumers and high performance of the sector. Sufficient conditions for digitalization are support for environmental protection together with high sector performance and, alternatively, the absence of management barriers. 
Table 9. Research propositions and their confirmation status.

\begin{tabular}{|c|c|}
\hline Propositions & Results \\
\hline $\begin{array}{l}\text { P1. Supporting environmental protection is a } \\
\text { necessary condition for achieving the expected } \\
\text { effects of digitalization in the energy industry. }\end{array}$ & $\begin{array}{l}\text { Not supported. However, supporting } \\
\text { environmental protection with higher } \\
\text { performance in the energy sector turned out to } \\
\text { be a core sufficient condition (shown in the } \\
\text { parsimonious solution). This implies a strong } \\
\text { contribution of this condition to the occurrence } \\
\text { of digitalization effects in the energy sector. }\end{array}$ \\
\hline $\begin{array}{l}\text { P2. Technological support of prosumers and } \\
\text { consumers is a necessary condition for achieving the } \\
\text { expected effects of digitalization in the energy sector. }\end{array}$ & Supported \\
\hline $\begin{array}{l}\text { P3. Higher performance in the energy sector is a } \\
\text { necessary condition for achieving the expected } \\
\text { effects of digitalization in the energy sector in } \\
\text { Poland: country considered as catching up economy }\end{array}$ & Supported \\
\hline $\begin{array}{l}\text { P4. Rapid deployment of new technologies is a } \\
\text { necessary condition for achieving the expected } \\
\text { effects of digitalization in the energy sector. }\end{array}$ & $\begin{array}{l}\text { Not supported. The findings did not confirm } \\
\text { the prioritization of rapid technology } \\
\text { deployment as a necessary or sufficient } \\
\text { condition for the digitalization effects to occur } \\
\text { in the energy sector. }\end{array}$ \\
\hline $\begin{array}{l}\text { P5. The absence of management and external } \\
\text { barriers is a necessary condition for the effects of } \\
\text { digitalization of the energy sector. }\end{array}$ & $\begin{array}{l}\text { Not supported. However, absence of } \\
\text { managerial barriers turned out to be a core } \\
\text { condition shown in the parsimonious solution. } \\
\text { Similar to the combined impact of support for } \\
\text { environmental protection and sector } \\
\text { performance, this condition has a considerable } \\
\text { impact on the occurrence of digitalization } \\
\text { effects in the energy sector. }\end{array}$ \\
\hline
\end{tabular}

Source: own research.

\section{Conclusions}

In this article we explore drivers for the digitalization of the energy sector in Poland, an EU member and catching up economy. Poland, bound by European Union ambitious plans to create an environmentally neutral energy system, in order to meet these objectives, faces a number of socialist legacy shortcomings. These include an outdated energy infrastructure based on traditional fossil sources, a large area with uneven coverage in the mining and transmission network and political favoritism of social groups from the traditional mining sector over the decades.

The paper examines views of the so-called insiders: people who are supposed to simultaneously implement EU energy policy goals (which clearly emphasizes environmental objectives as paramount in the transformation of the sector) on par with the national energy transformation plan, which points to priorities of system stability and efficiency. In both policies, the use of digital technologies as those supporting the achievement of transformational goals is indisputable. In the case of both the Polish and the EU plan, digital transformation is necessary and highlighted as crucial to achieve any and all goals. However, it appears that, in the case of Poland, in the opinion of energy sector managers, it is not the environment but the efficiency of the sector that comes to the fore. Meeting environmental requirements is important, but not a priority, and sets the necessary topdown conditions for transformation. Moreover, while digitalization of the sector is seen as a necessary condition for achieving better system efficiency, rapid implementation of the most relevant digital technologies (identified by managers, such as cloud computing, machine learning, blockchain, robotic process automation) is neither urgent nor necessary to ensure the achievement of the set transformation goals. Managers, despite demonstrating the necessity and benefits associated with the digitalization boosting companies' efficiency and improving cooperation with prosumers and consumers, do not consider the implementation of new digital technologies a priority. Such results make one wonder 
about the following issues. Firstly, digitalization of the energy sector appears as more of a buzzword than an urgent necessity for Polish managers taking part in the survey. Our research suggests that this may stem from either the digital technologies' knowledge and competence gap or techno-anxiety in terms of their possible application and potential benefits. These results may also explain lack of determination to introduce digital technologies in the near future, which puts into question the possibility of achieving the goals set out in both Polish and EU plans for the transformation of the energy sector.

As with any study, this one also suffers from a number of limitations. The first one considers the type of data, which are managers opinions about priorities, challenges, and digitalization outcomes. Even though the e-questionnaire was directed to professionals from the energy sector we still have to take into account the data subjectivity.

However, it seems that the concern about subjectivity or random answers in case of this survey is limited. Firstly, both reliability coefficients and unidimensionality of all aggregated variables are more than satisfactory, which implies that managers were quite unanimous in their responses. Secondly, as our findings do suggest gaps in digital technologies knowledge, competences, or indicate techno anxiety among managers, they also indicate that the answers were given quite frankly, and that the extent of these competence shortcomings in reality can only be greater.

Another limitation stems from the number of responses (44) and the method employed to analyze them. Despite the undoubted advantages of fsQCA and its suitability for small sample analysis, this method is not free from some weaknesses, such as lack of ability to create predictive models and quantify factor effects, or its unidirectionality. Therefore, all findings obtained and conclusions expressed should be treated with due caution, and as a stimulus for further in-depth research on larger samples focused on the following issues: (i) causes, manifestations and consequences of the diagnosed managerial barriers impeding the digitalization of the energy sector in Visegrád countries, (ii) opportunities, benefits and risks of introducing particular digital technologies in the energy production and distribution stages, (iii) the scope, nature of digital (in)competency and anxiety among employees and managers in the energetic sector together with ways of levelling them.

The research presented here demonstrates a managerial perspective on the transformation of the energy sector and the role of digital technologies in achieving it. In this paper, demonstrating the view of 'insiders', we show how the priorities described in international and national plans are perceived by those tasked with implementing them. It turns out that the perspective of the implementers of top-down plans is different from that of the creators and focuses on ensuring maximum efficiency, regardless of political declarations or catchphrases. The research also contributes to revealing the potential risks associated with the energy transition. The most significant problem appears in the lack of priority given to the rapid introduction of digital technologies despite the managers' emphasis on their overall importance and range of benefits. Such a reserved attitude, suggesting managers' knowledge deficits in this field and some kind of fear related to the implementation of such technologies, may have a broader, not only Polish, scope. This problem may be also visible in other catching up economies. The findings also allow to draw some recommendations at managerial and national level. Comprehensive training programs directed to the broad spectrum of the energy sector employees and aimed at "disenchanting" digital technologies should be urgently introduced. The programs should focus on explaining types, use of digital technologies and applications, showing their comprehensive usefulness while often being user-friendly. Energy companies and their staff face great challenge of transforming the entire sector towards an environmentally sustainable, stable, efficient system. Meeting these objectives requires substantial and direct help from national authorities and organizations. The priority of sustainable goals should be constantly emphasized, and the processes of digital transformation should be closely monitored and empowered, as this factor seems crucial for the whole transformation of the energy sector. 
Author Contributions: Conceptualization, J.Ś.-S. and B.S.; Methodology, J.Ś.-S. and B.S.; Software, J.Ś.-S.; Validation, J.Ś.-S.; Formal analysis, J.Ś.-S. and B.S.; Investigation, J.Ś.-S. and B.S.; Resources, J.S.-S. and B.S.; Data curation, J.Ś.-S. and B.S.; Writing—original draft preparation, J.S.-S. and B.S.; Writing—review and editing, J.Ś.-S. and B.S.; Visualization, J.S.-S. and B.S.; Funding acquisition, B.S. All authors have read and agreed to the published version of the manuscript.

Funding: The project financed within the Regional Initiative for Excellence program of the Minister of Science and Higher Education of Poland, years 2019-2022, grant No. 004/RID/2018/19 financing $3,000,000$ PLN.

Institutional Review Board Statement: Not applicable.

Informed Consent Statement: Not applicable.

Data Availability Statement: The data presented in this study are available on request from the corresponding author.

Conflicts of Interest: The authors declare no conflict of interest.

\section{Appendix A}

Table A1. Terminology abbreviations used in the paper.

\begin{tabular}{ll}
\hline \multicolumn{1}{c}{ Abbreviation } & \multicolumn{1}{c}{ Term } \\
\hline 3 DS' $^{\prime}$ & decarbonization, digitalization and decentralization \\
AI & Artificial Intelligence \\
ANN & Artificial Neural Networks \\
DER & Distributed Energy Resources \\
DER & Distributed Energy Resources \\
EFECTDIG & Effects of digitalization \\
EUROHPC JU & The European High Performance Computing Joint Undertaking \\
EXTBAR & External barriers to digitalization \\
FSQCA & Fuzzy set Qualitative Comparative Analysis \\
ICT & Internet Computer Technology \\
ICT INDICATOR & digital level for environmental sustainability \\
IEA & International Energy Agency \\
IOT & Internet of Things \\
IT & Internet Technology \\
MNGT BAR & Management barriers to digitalization \\
NEWTECH & Implementing new technologies \\
PEP2040 & Poland's Energy Policy plan until 2040 \\
PRACE & Partnership for Advanced Computing in Europe \\
PRI & Proportional Reduction in Inconsistency \\
RES & Renewable Energetic Sources \\
RPA & Robotic Process Automation \\
SECPERF & Energy sector performance \\
SUPENV & Support for environmental protection \\
SUPPROCO & Technological support for prosumers and consumers \\
\hline SOurce: $0 w n$ laboration &
\end{tabular}

\section{References}

1. Papadis, E.; Tsatsaronis, G. Challenges in the decarbonization of the energy sector. Energy 2020, 205, 118025. [CrossRef]

2. Bauer, N.; Calvin, K.; Emmerling, J.; Fricko, O.; Fujimori, S.; Hilaire, J.; van Vuuren, D.P. Shared socio-economic pathways of the energy sector-quantifying the narratives. Glob. Environ. Chang. 2017, 42, 316-330. [CrossRef]

3. Schaeffer, R.; Szklo, A.S.; de Lucena, A.F.P.; Borba, B.S.M.C.; Nogueira, L.P.P.; Fleming, F.P.; Boulahya, M.S. Energy sector vulnerability to climate change: A review. Energy 2012, 38, 1-12. [CrossRef]

4. Markovska, N.; Taseska, V.; Pop-Jordanov, J. SWOT analyses of the national energy sector for sustainable energy development. Energy 2009, 34, 752-756. [CrossRef]

5. Jacobsson, S.; Bergek, A. Transforming the energy sector: The evolution of technological systems in renewable energy technology. Ind. Corp. Chang. 2004, 13, 815-849. [CrossRef]

6. Umbach, F. Energy Security in a Digitalised World and its Geostrategic Implications. Konrad-Adenauer-Foundation (KAS), Hongkong, Regional Project Energy Security and Climate Change Asia-Pacific (RECAP). 2018. Available online: https://www.researchgate.net/publication/334131738_Energy_Security_in_a_Digitalised_World_and_its_Geostrategic_ Implications / citations (accessed on 11 December 2021).

7. Gunningham, N. Managing the energy trilemma: The case of Indonesia. Energy Policy 2013, 54, 184-193. [CrossRef] 
8. Akberdina, V.; Osmonova, A. Digital transformation of energy sector companies. E3S Web Conf. 2021, 250, 06001. [CrossRef]

9. World Energy Trilemma 2016: Defining Measures to Accelarate the Energy Transition. World Energy Council Report 2016. Available online: http:/ / www.worldenergy.org/publications/2016/world-energy-trilemma-2016-defining-measures-to-acceleratethe-energy-transition/ (accessed on 15 December 2021).

10. Popczyk, J. Od działań kryzysowych 2020 do elektroprosumeryzmu 2050, Transformacja energetyki w trybie przełomowym. Rozległe uwarunkowania i punkt oddolnego praktycznego startu, cz. II. Słownik encyklopedyczny teorii i zarys koncepcji rynku wschodzaccego 1 na poziomie praktyki, Platforma PPTE2050 (www.ppte2050.pl), 2020. Portal CIRE (www.cire.pl), 2020. Energetyka 2020, 5, 216-234.

11. Lipski, M. Wyzwania sektora energetycznego w Polsce z perspektywy akcjonariuszy. Zesz. Nauk. PWSZ Płocku Nauki Ekon. 2016, 1, 269-279.

12. Malko, J. Uwarunkowania polskiej polityki energetycznej. Polityka Energetyczna 2009, 12, 369-391.

13. Küfeoğlu, S.; Liu, G.; Anaya, K.; Pollitt, M.G. Digitalisation and New Business Models in Energy Sector. EPRG Working Paper 1920, Cambridge Working Paper in Economics 1956. 2019. Available online: https:/ /www.eprg.group.cam.ac.uk/wp-content/ uploads/2019/06/1920-Text.pdf (accessed on 10 November 2021).

14. Brown, M.; Woodhouse, S.; Sioshansi, F. Consumer, Prosumer, Prosumager: How Service Innovations Will Disrupt the Utility Business Model, 1st ed.; Academic Press: Cambridge, MA, USA, 2019; pp. 3-25.

15. Lyu, W.; Liu, J. Artificial Intelligence and emerging digital technologies in the energy sector. Appl. Energy 2021, $303,117615$. [CrossRef]

16. Ren, S.; Hao, Y.; Xu, L.; Wu, H.; Ba, N. Digitalization and energy: How does internet development affect China's energy consumption? Energy Econ. 2021, 98, 105220. [CrossRef]

17. Zhu, S.; Song, M.; Lim, M.K.; Wang, J.; Zhao, J. The development of energy blockchain and its implications for China's energy sector. Resour. Policy 2020, 66, 101595. [CrossRef]

18. Alekseev, A.; Lobova, S.; Bogoviz, A.; Ragulina, J. Digitalization of the Russian Energy Sector: State-of-the-art and Potential for Future Research. Int. J. Energy Econ. 2019, 9, 274-280. [CrossRef]

19. Gibadullin, A.A.; Pulyaeva, V.N.; Yerygin, Y.V. The need for a digital substation during the digitalization of energy. In Proceedings of the 2018 International Youth Scientific and Technical Conference Relay Protection and Automation (RPA), Moscow, Russia, 27-28 September 2018; pp. 1-12.

20. Chebotareva, G. Digital transformation of the energy sector: A case of Russia. E3S Web Conf. 2021, 250, 01001. [CrossRef]

21. Osmundsen, K. Competences for Digital Transformation: Insights from the Norwegian Energy Sector. In Proceedings of the 53rd Hawaii International Conference on System Sciences, HICSS, Wailea, HI, USA, 7 January 2020; pp. 4326-4335.

22. Hossein Motlagh, N.; Mohammadrezaei, M.; Hunt, J.; Zakeri, B. Internet of Things (IoT) and the energy sector. Energies 2020, 13, 494. [CrossRef]

23. Nagasawa, T.; Pillay, C.; Beier, G.; Fritzsche, K.; Pougel, F.; Takama, T.; The, K.; Bobashev, I. Accelerating Clean Energy through Industry 4.0: Manufacturing the Next Revolution; A Report of the United Nations Industrial Development Organization; United Nations Industrial Development Organization: Vienna, Austria, 2020.

24. Digitalisation and Energy, IEA 2017, Paris. Available online: https://www.iea.org/reports/digitalisation-and-energy (accessed on 10 December 2021).

25. Legner, C.; Eymann, T.; Hess, T.; Matt, C.; Böhmann, T.; Drews, P.; Mädche, A.; Urbach, N.; Ahlemann, F. Digitalization: Opportunity and Challenge for the Business and Information Systems Engineering Community. Bus. Inf. Syst. Eng. 2017, 59, 301-308. [CrossRef]

26. Weigel, P.; Fischedick, M. Review and categorization of digital applications in the energy sector. Appl. Sci. 2019, 9, 5350. [CrossRef]

27. Vial, G. Understanding digital transformation: A review and a research agenda. J. Strateg. Inf. Syst. 2019, 28, 118-144. [CrossRef]

28. Verma, P.; Savickas, R.; Buettner, S.M.; Strüker, J.; Kjeldsen, O.; Wang, X. Digitalization: Enabling the New Phase of Energy Efficiency. Group of Experts on Energy Efficiency, GEEE-7, 2020, NF.3. Available online: https://unece.org/sites/default/files/ 2020-12/GEEE-7.2020.INF_.3.pdf (accessed on 10 November 2021).

29. Kettunen, P.; Mäkitalo, N. Future smart energy software houses. Eur. J. Futures Res. 2019, 7, 1-25. [CrossRef]

30. Singh, M.; Jiao, J.; Klobasa, M.; Frietsch, R. Emergence of digital and X-as-a-service (XAAS) platforms in German energy sectors In Proceedings of the 1st IAEE Online Conference: Energy, COVID, and Climate Change, Paris, France, 7-9 June 2021. Available online: https:/ / www.iaee.org/proceedings/article/17486 (accessed on 20 November 2021).

31. Strüker, J.; Albrecht, S.; Reichert, S. Blockchain in the energy sector. In Business Transformation through Blockchain; Palgrave Macmillan: Cham, Switzerland, 2019; pp. 23-51.

32. Krajnakova, E.; Svazas, M.; Navickas, V. Biomass blockchain as a factor of energy sustainability development. Entrep. Sustain. Issues 2019, 6, 1456-1467. [CrossRef]

33. Mengelkamp, E.; Notheisen, B.; Beer, C.; Dauer, D.; Weinhardt, C.A. Blockchain-based smart grid: Towards sustainable local energy markets. Comput. Sci. 2018, 33, 207-214. [CrossRef]

34. Sozontov, A.; Ivanova, M.; Gibadullin, A. Implementation of artificial intelligence in the electric power industry. E3S Web Conf. 2019, 114, 01009. [CrossRef] 
35. Loseva, O.V.; Karpova, S.V.; Rasteryaev, K.O.; Sokolova, E.S.; Makar, S.V.; Kharchilava, K.P. Sustainable Energy in Island States: Comparative Analysis of New Trends in Energy Digitalization and the Experience of the UK, Japan, Indonesia and Cyprus. Int. J. Energy Econ. Policy 2020, 10, 722. [CrossRef]

36. Mosavi, A.; Salimi, M.; Faizollahzadeh Ardabili, S.; Rabczuk, T.; Shamshirband, S.; Varkonyi-Koczy, A.R. State of the art of machine learning models in energy systems, a systematic review. Energies 2019, 12, 1301. [CrossRef]

37. Ramchurn, S.D.; Vytelingum, P.; Rogers, A.; Jennings, N.R. Putting the 'smarts' into the smart grid: A grand challenge for artificial intelligence. Commun. ACM 2012, 55, 86-97. [CrossRef]

38. Andoni, M.; Robu, V.; Flynn, D.; Abram, S.; Geach, D.; Jenkins, D.; Peacock, A. Blockchain technology in the energy sector: A systematic review of challenges and opportunities. Renew. Sustain. Energ. Rev. 2019, 100, 143-174. [CrossRef]

39. Helm, D. Energy policy: Security of supply, sustainability and competition. Energy Policy 2002, 30, 173-184. [CrossRef]

40. Helm, D. The New Energy Paradigm. Oxf. Rev. Econ. Policy 2007, 21, 9-35. [CrossRef]

41. Costa-Campi, M.T.; del Rio, P.; Trujillo-Baute, E. Trade-offs in energy and environmental policy. Energy Policy 2017, 104, 415-418. [CrossRef]

42. Trutnevyte, E.; Strachan, N.; Dodds, P.E.; Pudjianto, D.; Strbac, G. Synergies and trade-offs between governance and costs in electricity system transition. Energy Policy 2015, 85, 170-181. [CrossRef]

43. Allen, M.L.; Allen, M.M.C.; Cumming, D.; Johan, S. Comparative Capitalisms and Energy Transitions: Renewable Energy in the European Union. Br. J. Manag. 2021, 19, 611-629. [CrossRef]

44. Tutak, M.; Brodny, J.; Siwiec, D.; Ulewicz, R.; Bindzár, P. Studying the level of sustainable energy development of the European Union countries and their similarity based on the economic and demographic potential. Energies 2020, 13, 6643. [CrossRef]

45. Kryk, B. Ensuring sustainable energy as a sign of environmental responsibility and social justice in European Union members. Econ. Environ. 2019, 71, 25. [CrossRef]

46. Article 194 of the Treaty on the Functioning of the European Union, TFEU, Energy Union 2015. Available online: http:/ / data. europa.eu/eli/treaty/tfeu_2012/art_194/oj (accessed on 8 December 2021).

47. Gharavi, H. Scanning the Issue Smart Grid: The Electric Energy System of the Future. Proc. IEEE 2011, 99, 917-921. [CrossRef]

48. Wissner, M. The Smart Grid-A saucerful of secrets? Appl. Energy 2011, 88, 2509-2518. [CrossRef]

49. Madni, A.M.; Madni, C.C.; Lucero, S.D. Leveraging digital twin technology in model-based systems engineering. Systems 2019, 7, 7. [CrossRef]

50. Lacity, M.; Willcocks, L.P.; Craig, A. Robotic Process Automation: Mature Capabilities in the Energy Sector. The Outsourcing Unit Working Research Paper Series Paper 2015, 06. Available online: http://eprints.lse.ac.uk/64520/1/OUWRPS_15_06_published. pdf (accessed on 10 December 2021).

51. Wach, K.; Głodowska, A.; Maciejewski, M.; Sieja, M. Europeanization processes of the EU energy policy in Visegrad countries in the years 2005-2018. Energies 2021, 14, 1802. [CrossRef]

52. Solorio, I.; Jörgens, H. Contested energy transition? Europeanization and authority turns in EU renewable energy policy. J. Eur. Integr. 2020, 42, 77-93. [CrossRef]

53. Stavytskyy, A.V.; Kharlamova, G.; Giedraitis, V.; Šumskis, V. Estimating the interrelation between energy security and macroeconomic factors in European countries. J. Int. Stud. 2018, 11, 217-238. [CrossRef]

54. Strunz, S.; Gawel, E.; Lehmann, P. Towards a general "Europeanization" of EU Member States energy policies? Econ. Energy Environ. Policy 2015, 4, 143-160. [CrossRef]

55. Chester, L. Conceptualising energy security and making explicit its polysemic nature. Energy Policy 2010, 38, 887-895. [CrossRef]

56. Share of Energy from Renewable Sources. Eurostat, NRG_IND_REN. Available online: https://ec.europa.eu/eurostat/ databrowser/view/nrg_ind_ren/default/table?lang=en (accessed on 5 February 2022).

57. Directive 2009/28/EC of the European Parliament and of the Council of 23 April 2009 on the Promotion of the Use of Energy from Renewable Sources and Amending and Subsequently Repealing Directives 2001/77/EC and 2003/30/EC. Available online: https:/ / eur-lex.europa.eu/legal-content/EN/ALL/?uri=CELEX\%3A32009L0028 (accessed on 5 February 2022).

58. Willis, H.L.; Scott, W.G. Distributed Power Generation. Planning and Evaluation; CRC Press: New York, NY, USA, 2018.

59. Herran, D.S.; Nakata, T. Design of decentralised energy systems for rural electrification in developing countries considering regional disparity. Appl. Energy 2012, 91, 130-145. [CrossRef]

60. Ackerman, A.S.; Toon, O.B.; Taylor, J.P.; Johnson, D.W.; Hobbs, P.V.; Ferek, R.J. Effects of aerosols on cloud albedo: Evaluation of Twomey's parameterisation of cloud susceptibility using measurements of ship tracks. J. Atmos. Sci. 2000, 57, 2684-2695. [CrossRef]

61. Śleszyński, P.; Nowak, M.; Brelik, A.; Mickiewicz, B.; Oleszczyk, N. Planning and settlement conditions for the development of renewable energy sources in Poland: Conclusions for local and regional policy. Energies 2021, 14, 1935. [CrossRef]

62. The Digital Economy and Society Index 2021-Countries' Performance in Digitisation. Available online: https:/ / digital-strategy. ec.europa.eu/en/policies / countries-digitisation-performance (accessed on 13 December 2021).

63. Ministry of Climate and Environment Ministry of Energy. Poland's Energy Policy Until 2040 (PEP 2040). 2018. Available online: https:/ / www.gov.pl/web/klimat/polityka-energetyczna-polski (accessed on 13 October 2021).

64. Rezny, L.; White, J.B.; Maresova, P. The knowledge economy: Key to sustainable development? Struct. Chang. Econ. Dyn. 2019, 51, 291-300. [CrossRef] 
65. Dos Santos Gaspar, J.; Marques, A.C.; Fuinhas, J.A. The traditional energy-growth nexus: A comparison between sustainable development and economic growth approaches. Ecol. Indic. 2017, 75, 286-296. [CrossRef]

66. Fortunski, B. Challenges and problems of sustainable development in world energy in the context of EU energy policy. Intern. Trade 2013, 1, 300-310.

67. Sassi, O.; Crassous, R.; Hourcade, J.C.; Gitz, V.; Waisman, H.; Guivarch, C. IMACLIM-R: A modelling framework to simulate sustainable development pathways. Int. J. Glob. Environ. Issues 2010, 10, 5-24. [CrossRef]

68. Pultowicz, A. Rationale for the development of the renewable energy sources market in Poland in the light of the idea of sustainable development. Probl. Ekorozw. 2009, 4, 109-115.

69. Stern, D.I.; Common, M.S.; Barbier, E.B. Economic growth and environmental degradation: The environmental Kuznets curve and sustainable development. World Dev. 1996, 24, 1151-1160. [CrossRef]

70. Litvinenko, V.S. Digital economy as a factor in the technological development of the mineral sector. Nat. Resour. Res. 2020, 29, 1521-1541. [CrossRef]

71. Shove, E. Energy efficiency. In Energy Fables: Challenging Ideas in the Energy Sector; Rinkinen, J., Shove, E., Torriti, J., Eds.; Routledge: London, UK, 2019; pp. 29-38.

72. Ilomäki, L.; Paavola, S.; Lakkala, M.; Kantosalo, A. Digital competence-an emergent boundary concept for policy and educational research. Educ. Inf. Technol. 2016, 21, 655-679. [CrossRef]

73. Ferrari, A. DIGCOMP: A Framework for Developing and Understanding Digital Competence in Europe. EUR 26035; Publications Office of the European Union: Luxembourg, 2013.

74. Berkhout, F.; Hertin, J. De-materialising and re-materialising: Digital technologies and the environment. Futures 2004, 36, 903-920. [CrossRef]

75. Manny, L.; Duygan, M.; Fischer, M.; Rieckermann, J. Barriers to the digital transformation of infrastructure sectors. Policy Sci. 2021, 54, 943-983. [CrossRef] [PubMed]

76. Marcon, É.; Marcon, A.; Le Dain, M.-A.; Ayala, N.F.; Frank, A.G.; Matthieu, J. Barriers for the digitalization of servitization. Procedia CIRP 2019, 83, 254-259. [CrossRef]

77. Lewin, K. Field Theory in Social Science; Harper: New York, NY, USA, 1951.

78. The Polish Electric Power Industry Association (Polskie Stowarzyszenie Branży Elektroenergetycznej-PSBE). Available online: https://psbe.org.pl/en/start/ (accessed on 20 November 2021).

79. Renewable Energy Association (Stowarzyszenie energi odnawialnej -SEO). Available online: http://seo.org.pl/en/o-nas/ (accessed on 20 November 2021).

80. Kompass. Available online: https://pl.kompass.com/en (accessed on 16 October 2021).

81. Ragin, C.C. User's Guide to Fuzzy-Set/Qualitative Comparative Analysis 3.0; Department of Sociology, University of California: Irvine, CA, USA, 2018.

82. Kwiotkowska, A. Qualitative comparative analysis as a methodological concept in management sciences. Pr. Nauk. Uniw. Ekon. Wroctawiu 2014, 340, 65-77.

83. Mello, P.A. Qualitative Comparative Analysis: An Introduction to Research Design and Application; Georgetown University Press: Washington, DC, USA, 2021.

84. Ragin, C.C. Fuzzy-Set Social Science; The University of Chicago Press: Chicago, IL, USA, 2000.

85. Ragin, C.C. Redesigning Social Inquiry: Fuzzy Sets and Beyond; University of Chicago Press: Chicago, IL, USA, 2008.

86. Ragin, C.C.; Davey, S. Fuzzy-Set/Qualitative Comparative Analysis 3.0; Department of Sociology, University of California: Irvine, CA, USA, 2016.

87. Pappas, I.O.; Woodside, A.G. Fuzzy-set Qualitative Comparative Analysis (fsQCA): Guidelines for research practice in Information Systems and marketing. Int. J. Inf. Manag. 2021, 58, 102310. [CrossRef]

88. Ragin, C.C. Qualitative Comparative Analysis Using Fuzzy Sets (FSQCA). In Configurational Comparative Methods: Qualitative Comparative Analysis (QCA) and Related Techniques; Rihoux, B., Ragin, C.C., Eds.; Sage Publication: Thousand Oaks, CA, USA; London, UK, 2009; pp. 87-122.

89. Schneider, C.Q.; Wagemann, C. Set-Theoretic Methods for the Social Sciences: A Guide to Qualitative Comparative Analysis; Cambridge University Press: Cambridge, UK, 2012.

90. Ragin, C.C. How to lure analytic social science out of the doldrums: Some lessons from comparative research. Int. Sociol. 2006, 21, 633-646. [CrossRef]

91. Fiss, P.C. Building better causal theories: A fuzzy set approach to typologies in organization research. Acad. Manag. J. 2011, 54, 393-420. [CrossRef]

92. Osiceanu, M.E. Psychological implications of modern technologies: "technofobia" versus "technophilia". Procedia Soc. Behav. Sci. 2015, 180, 1137-1144. [CrossRef]

93. Khasawneh, O.Y. Technophobia without boarders: The influence of technophobia and emotional intelligence on technology acceptance and the moderating influence of organizational climate. Comput. Hum. Behav. 2018, 88, 210-218. [CrossRef]

94. Młody, M.; Weinert, A. The importance of technological anxiety for the digital transformation of industrial processing companies in Poland. In Contemporary Organisation and Management. Challenges and Trends; Michałkiewicz, A., Mierzejewska, W., Eds.; Wydawnictwo Uniwersytetu Łódzkiego: Łódź, Poland, 2020; pp. 15-34. [CrossRef] 